\title{
DETERMINANT OF FINANCIAL REPORTING QUALITY: TAX INCENTIVES, CORPORATE INVESTMENT EFFICIENCY AND GOOD CORPORATE GOVERNANCE
}

\author{
Indraguna Kusumabrata ${ }^{1}$ and Etty Murwaningsari ${ }^{2}$ \\ ${ }^{1}$ Student of Doctoral Trisakti University, Indonesia \\ ${ }^{2}$ Lecturer of Doctoral Trisakti University, Indonesia \\ DOI: http://dx.doi.org/10.38193/IJRCMS.2021.3510
}

\begin{abstract}
This study aims to determine the effect of the quality of financial reporting and tax incentives on corporate investment efficiency with good corporate governance as a moderating variable. The sample in this study consisted of 120 observations of property, real estate and building construction companies that published financial statements for 2009 - 2018 listed on the Indonesia Stock Exchange. This study uses a multiple regression data analysis tool with the help of Stata 13 software. The results of this study indicate there is an influence of the quality of financial reporting on corporate investment efficiency and there is an influence of good corporate governance on corporate investment efficiency through the quality of financial reporting. Also, there is no effect of tax incentives on corporate investment efficiency and there is no effect of good corporate governance on corporate investment efficiency through tax incentives.
\end{abstract}

KEYWORDS: corporate investment efficiency, quality of financial reporting, tax incentives, good corporate governance

\section{INTRODUCTION}

Investment activities are activities carried out on a variety of questions and discussions that are expected to bring benefits in the future. An investment is expected to provide positive added value, in the sense that the present value of cash flow that will be generated in the future is greater than the costs (Finnerty \& Emery, 2004). To achieve efficiency, investments must be made in accordance with needs. Investment will be efficient if the company avoids overinvestment (lack of capital) and underinvestment (excess capital). Managers must be able to read the right investment opportunities for the company (Hope dan Thomas, 2008). Biddle et al., (2009) argue that company can experience underinvestment when loses a project that brings a positive NPV, and overinvestment is when the company invests in a project with a negative NPV. 


\section{International Journal of Research in Commerce and Management Studies}

ISSN 2582-2292

Vol. 3, No. 05 Sep-Oct; 2021

PICTURE 1. Investation Realization Development in Indonesia 2014 - 2019

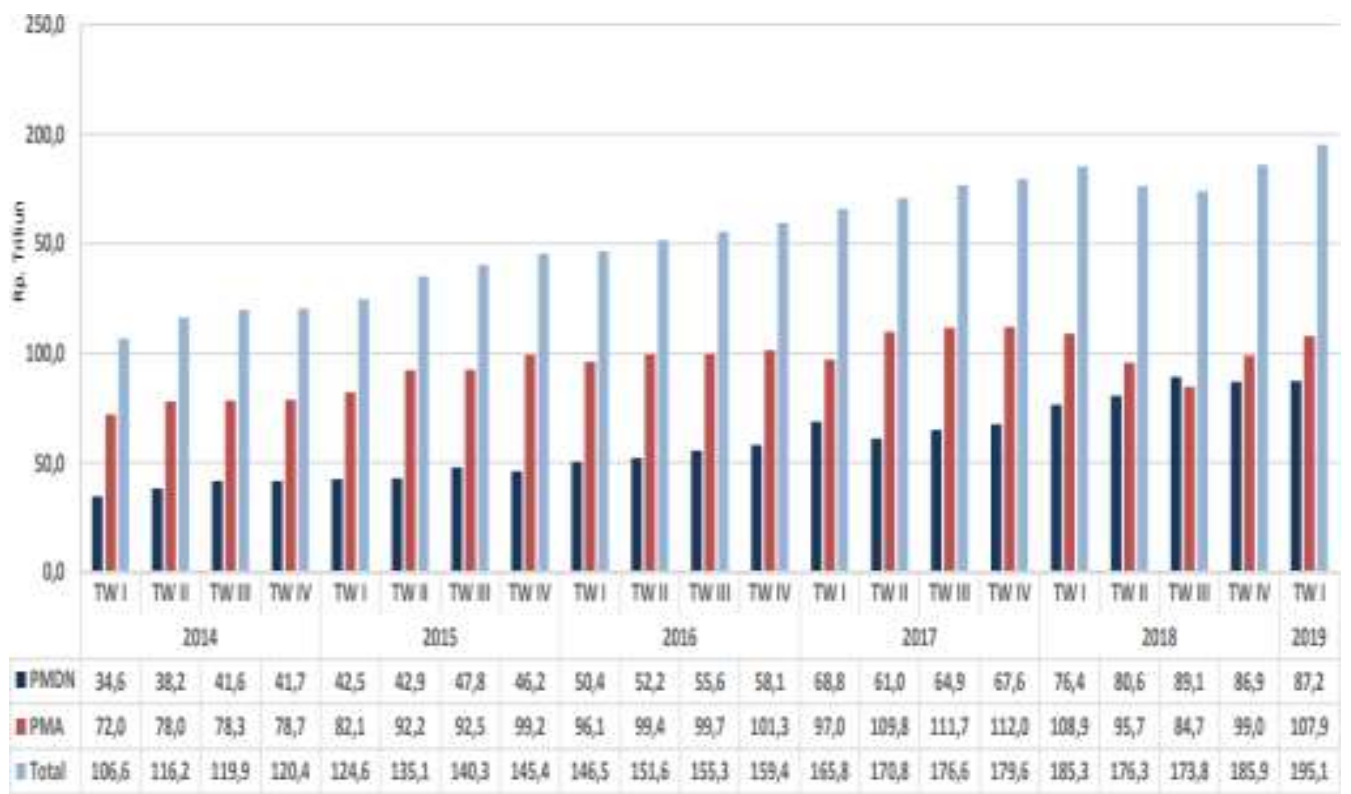

Source: https://www.bkpm.go.id/

Based on the above data, the Investment Coordinating Board (BKPM) published investment realization data for Quarter I (January-March period) in 2019, with a total investment of IDR195.1 trillion, up 5.3\% compared to the same period in 2018, which amounted to IDR185 9 trillion. The investment value during the First Quarter of 2019 for Domestic Investment (PMDN) was IDR87.2 trillion and Foreign Investment (PMA) was IDR107.9 trillion. During the first quarter of 2019, there were 235,401 Indonesian workers absorbed.

This investment realization achievement is very important to ensure that economic growth of $5.3 \%$ in 2019 can be realized. Compared to 2018, investment growth in domestic investment in the first quarter of 2019 increased by $14.1 \%$, from IDR76.4 trillion in the first quarter of 2018 to IDR87.2 trillion. Meanwhile, FDI investment in the first quarter of 2019 dropped $0.9 \%$ compared to the first quarter of 2018, which amounted to IDR108.9 trillion to IDR107.9 trillion.

The best decisions for investment, is influenced by the quality of good financial statements. The high quality of financial reporting can attract funding providers from outside to provide funding to the company so that it can mitigate the occurrence of underinvestment. The high quality of financial reporting will also reduce management's discretion and make it easier to assess optimal investment, thereby preventing management from overinvestment (Handayani et al., 2015). Errors in decision making and management's inability to oversee financial conditions may make investments made by the company wrong. Good Corporate Governance is also another non-financial factor that is currently 
being considered by many investors in valuing a company. The best GCG implementation is that following applicable regulations will make investors respond positively to the company's performance and increase the company's market price (Bagita \& Tambun, 2016). The next factor seen by investors for investment in a company is evaluating tax rates, guarantees, and various incentives that will be obtained (Nam \& Radulescu, 2004). Developing countries such as Malaysia and Mauritius, and developed countries such as Singapore, Taiwan and South Korea is use tax incentives to promote investment. Application of reducing corporate income tax rates, providing periodic exemptions on corporate taxes (tax holidays), which allow additional investment from deduction of tax obligations (through tax credit or investment allowances), and others. In economic activities that try to allocate or attract capital investment from within and outside the country, this is done by certain governments in economic activities that try to allocate or attract capital investment from within and outside the country (Putri, 2017).

\section{LITERATURE REVIEW DAN HIPOTESIS}

The agency problem was initially explored by Ross (1973), while the detailed theoretical exploration of agency theory was first stated by Jensen \& Meckling (1976) mentioning the manager of a company as an "agent" and a "principal" shareholder. Agency theory be famous because there is a relationship between managers and shareholders in which there are differences in interests between them. These differences in interests give rise to information asymmetry. Information asymmetry is the difference in information obtained between managers and shareholders. The emergence of moral hazard and adverse selection problems can encourage over-investment and under-investment. According to Januardi \& Afrianto (2017), companies with overinvestment problems in general are companies that are in the mature stage with a slow growth rate (slow growth), and have high assets in place and free cash flow. Companies with a high degree of leverage will tend to experience these conditions. If the company is unable to realize the investment as expected, the company must look for additional funding alternatives.

\section{Effect of the Quality of Financial Reporting on Corporate Investment Efficiency}

Rahmawati \& Harto's (2014) research show that the quality of financial statements has a positive influence on investment efficiency. Ahuja \& Novelli (2017) explained, if an overinvestment occurs, the company can reduce investment if the financial statements have been presented with quality. Overinvestment conditions illustrate that the amount of investment made, but the company only makes a little profit. From the above statement it can be drawn a hypothesis:

$\mathrm{H} 1=$ There is an effect of the Quality of Financial Reporting on Corporate Investment Efficiency.

\section{Effect of Tax Incentives on Corporate Investment Efficiency}

Klemm \& van Parys (2012) findings that tax holidays are only effective in a few cases that can be 
confirmed. Lumbantobing (2008) conducted a study which showed that the incentive tax policy was not significantly related to the investment climate of foreign investment companies in Indonesia. Rego \& Wilson (2012) examined the impact of income tax incentives on foreign capital investment using macroeconomic data sourced from secondary data and descriptive statistical analysis with comparative evaluation methods. The results showed that the provision of income tax incentives did not have a significant impact on foreign capital investment or it could be said that income tax incentives were not a major factor in investment decisions. From the above statement it can be drawn a hypothesis:

$\mathrm{H} 2$ : There is no effect of Tax Incentives on Corporate Investment Efficiency.

\section{Moderation of Good Corporate Governance on the Effect of Quality of Financial Reporting on Corporate Investment Efficiency}

According to Heenetigala \& Armstrong (2011), Good Corporate Governance is very effective in ensuring that the interests of stakeholders have been protected. The existence of accurate financial reporting quality supported by the application of Good Corporate Governance, is expected to increase investor confidence in the quality of financial reporting so that investment activities in a company will run well and optimally. From the above statement it can be drawn a hypothesis:

H3: There is an influence of Good Corporate Governance on Corporate Investment Efficiency through the Quality of Financial Reporting.

\section{Moderation of Good Corporate Governance on the Effects of Tax Incentives Towards Corporate Investment Efficiency}

Research by Mahenthrian \& Kasipillai (2014) explains that tax planning requires professional skills and expertise, and that a large number of boards of commissioners can influence a company's access to the necessary human resources capabilities. According to Bulutoding (2016) the price of a company's shares is high, hence the welfare of its shareholders is also high and vice versa which gives effect to the company's investment more effectively and efficiently. From the above statement it can be drawn a hypothesis:

H4: There is an influence of Good Corporate Governance on Corporate Investment Efficiency through Tax Incentives.

\section{Effect of Good Corporate Governance toward Corporate investment efficiency}

According to Salami (2011) corporate governance is an important part in determining the investment strategy of a company, because in determining investment can spur agency problems and also conflict of interest, this can be suppressed by implementing corporate governance in the company. The same thing was expressed by Drobetz \& Fix (2003), who found evidence in his research that companies with a high level of corporate governance can produce good performance (high $\mathrm{Q}$ tobacco rates).

H5: There is an effect of Good Corporate Governance on Corporate Investment Efficiency. 


\section{International Journal of Research in Commerce and Management Studies}

ISSN 2582-2292

Vol. 3, No. 05 Sep-Oct; 2021

\section{RESEARCH METHOD}

The population in this study are service companies in the property, real estate and building construction subsectors that were listed on the Indonesia Stock Exchange in 2009-2018. Determination of the sample in this study was conducted by using purposive sampling method. The criteria used are as follows:

a. The company used is the property, real estate and building construction subsector services company that was listed on the Indonesia Stock Exchange in 2009-2018.

b. Companies that have financial statements that have been audited and published in full.

c. Companies that have data relating to research variables and are available in full.

The data used in this study is secondary data. This data is in the form of financial statements from companies engaged in property, real estate and building construction services. The data is sourced from the Indonesia Stock Exchange which was publish in 2008-2018. The dependent variable in this study is Corporate Investment Efficiency. Measurement of Corporate Investment Efficiency using a model conducted by Biddle et al., (2009) by formula:

$$
\text { Investment }=\frac{[(\text { capex }+R \& D+\text { acquire })-(\text { PPEsales })]}{\text { Total assets }} \times 100
$$

Variance in the quality of financial statement quality is proxied by accrual quality. To be able to measure the value of the accruals, this research will follow the accrual measurement model conducted by (Kothari et al., 2005) with the following formula:

\section{Total Accrual $=$ Net Income + Depreciation - Cash Flow From Operation}

Tax incentives in this study are proxied by using tax planning, which is an effort made by managers to minimize the company's tax burden in the current year and in the future. The tax planning in this study was calculated using the formula (Midiastuty et al., 2018):

$$
\text { Tax Plan }=\frac{\sum t[(30 \% P T I)-C T E]}{T A t}
$$

Control variable in this study is Good Corporate Governance by Klapper and Love (2004) formula:

$$
\text { Performance }=b_{0}+b_{1} C G+b_{2} \text { Assets Compositon }+b_{3} \text { opportunity to growth }+b_{4} \text { LnSales }+e
$$


ISSN 2582-2292

Vol. 3, No. 05 Sep-Oct; 2021

\section{RESULT AND DISCUSSION}

This research is using a number of per-year-old internet sites that are located in Indonesia on 2009 2018 all of which are located in Indonesia. The following is a prose as a result of the one to be elaborated on the 1 st table:

TABLE 1. Criteria of Sample

\begin{tabular}{|c|l|l|}
\hline No & \multicolumn{1}{|c|}{ Criteria } & $\begin{array}{l}\text { Number } \\
\text { Company }\end{array}$ \\
\hline 1. & $\begin{array}{l}\text { Property, real estate and build construction listed } \\
\text { on IDX 2009 - 2018 }\end{array}$ & 81 \\
\hline 2. & $\begin{array}{l}\text { Companies that do not have financial reports that } \\
\text { have been audited and published completely }\end{array}$ & $(43)$ \\
\hline 3. & $\begin{array}{l}\text { Companies that do not have data related to the } \\
\text { research variable and available in full }\end{array}$ & $(26)$ \\
\hline & Companies on sample & 12 \\
\hline
\end{tabular}

Descriptive statistics provide a description or descriptive data that is seen from the average value (mean), standard deviation, variance, minimum value and maximum value

TABLE 2. Statistics Descriptive Test

\begin{tabular}{|l|c|l|l|l|l|}
\hline Variable & Obs & Mean & Std.Dev & Min & Max \\
\hline CIE & 120 & 2.063725 & 4.05565 & 0.007 & 23.873 \\
\hline FRQ & 120 & 0.0386667 & 0.0025149 & 0.034 & 0.05 \\
\hline TI & 120 & 0.2269252 & 0.0960827 & 0 & 0.5089204 \\
\hline GCG & 120 & 0.349833 & 0.0012298 & 0.033 & 0.038 \\
\hline $\begin{array}{l}\text { Corporate Investment Efficiency measure by capital expenditure plus R\&D } \\
\text { plus acquisition expenditure minus PPE Sales multiple 100 divided total aset. }\end{array}$ \\
$\begin{array}{l}\text { Financial Report Quality measure by net income plus depreciation minus cash } \\
\text { flow from operation. Tax Incentives measure by pre-tax income minus tax } \\
\text { expense divided total asset. GCG measure by company assets composition } \\
\text { plus opportunity growth plus firm size. }\end{array}$ \\
\hline \multicolumn{7}{|l}{}
\end{tabular}

Normality test is aims to know about the data that it's set to be normal as it is, or not. 
ISSN 2582-2292

Vol. 3, No. 05 Sep-Oct; 2021

\section{TABLE 3. Normality Test Kolmogorov Ksmirnov}

\begin{tabular}{|c|c|c|c|}
\hline \multicolumn{4}{|c|}{$\begin{array}{l}\text { One-sampel Kolmogorov-Smirnov test against theoreticial distribution } \\
\text { normal }((\text { resid-r(mean }) / r(s d))\end{array}$} \\
\hline Smaller group & D & p-value & Corrected \\
\hline Reside & 0.0637 & 0.377 & \\
\hline Cumulative & -0.0530 & 0.510 & \\
\hline Combined K-S & 0.0637 & 0.714 & 0.674 \\
\hline
\end{tabular}

Based on table 3. shows that only the normal test is about 0.05 or $0.714>0.05$. That is just what is used in the study, this is normal. the conclusion that can be drawn is that the data of this study are normally distributed. Heteroskedasticity test as this is intended to test Some of the Regression models occur in the form of a variant from the rest of the reverie to the reception. To detected the symptoms of heteroskedasticity in this research using Cook-Weisberg Test.

TABLE 4. Heteroskedasticity test

\begin{tabular}{|l|l|}
$\begin{array}{l}\text { Breusch-Pagan/Cookweisberg test for heterokedastisitas } \\
\text { H0: Constants variances } \\
\text { Variable: fitted value of cie }\end{array}$ \\
\hline Chi2 (1) & 0.09 \\
\hline Prob $>$ chi2 & 0.7617 \\
\hline
\end{tabular}

Based on table 4 the heterokedastisity test, probability value > chi square, this is 0.7617 greater form level of significance 0.05 . So it can be conclude that there is no the symptoms of heterokedastisity in this research.

To determine the linier relationship between independent variables in the regression model that is formed, multicollinearity test is used. Tolerance value and variance inflation factor is 0.10 or VIF up to 10 . Otherwise in this research there is no multicollinearity. See table 5. 
TABLE 5. Multicollinearity Test

\begin{tabular}{|l|l|l|}
\hline \multicolumn{1}{|c|}{ Variable } & \multicolumn{1}{c|}{ VIF } & \multicolumn{1}{c|}{ 1/VIF } \\
\hline FRQ & 1.73 & 0.577666 \\
\hline CIE & 1.70 & 0.588836 \\
\hline GCG & 1.20 & 0.831884 \\
\hline TI & 1.13 & 0.887289 \\
\hline Mean VIF & 1.44 & \\
\hline
\end{tabular}

Autocorrelation test aims to find a strong relationship both positive and negative or there is no relationship between the data that exists on the research variables. In this research prob value is bigger than $\mathrm{F}$ value. It means that the data is free from autocorrelation 0.0848 . See table 6 .

TABLE 6. Autocorrelation Test

\begin{tabular}{|l|l|}
\hline \multicolumn{2}{|c|}{$\begin{array}{l}\text { Worldridge test for autocorelation in panel data H0: no first-order } \\
\text { aurocorelation }\end{array}$} \\
\hline $\mathrm{F}(1,11)$ & 3.586 \\
\hline Prob $>\mathrm{F}$ & 0.0848 \\
\hline
\end{tabular}

The result of testing the regression model in this study include the variable quality of financial reporting on corporate investment efficiency shows a significance value is $0.0049<0.05$, it means there is an effect of the quality of financial report in on corporate investment efficiency. Inversely proportional to the results of research conducted by Lara et al., (2007) which proves that there is no effect of financial statement quality toward investment efficiency. Results of hypothesis second testing shows that there is no a significance from tax incentives and corporate investment efficiency with 0.193, this value bigger than 0.05. these results same with Lumbntobing (2008) which proves there is no effect from tax incentives and corporate investment. Another hypothesis in this research measures the moderation of good corporate governance on the effect of the quality of financial reporting on corporate investment efficiency. The results showed significance of 0.048 so it can be concluded that there is effect of good corporate governance toward corporate investment efficiency through financial statement quality. The fourth hypothesis proves that the effect of tax incentives on corporate investment efficiency through good corporate governance has no influence. This can be seen from the probability value of 0.158 . the regression model result in this study include variables of good corporate governance on corporate investment efficiency showing a significance value of 0.767 . it 
ISSN 2582-2292

Vol. 3, No. 05 Sep-Oct; 2021

means there is no effect of good corporate governance toward corporate investment efficiency. See Table 7.

TABEL 7. Linear Regresi Test

\begin{tabular}{|c|c|c|c|c|}
\hline \multicolumn{5}{|c|}{ CIE it $=\alpha+\beta_{1}$ FRQ $+\beta_{2}$ TI $+\beta_{3}$ GCG $+\beta_{4}$ KPKGCG $+\beta_{5}$ TIGCG $+\varepsilon_{i t}$} \\
\hline \multicolumn{5}{|c|}{$\mathrm{H}_{1:}$ Financial Statement Quality toward Corporate Investment Efficiency } \\
\hline \multicolumn{5}{|c|}{$\mathrm{H}_{2:}$ Tax Incentives toward Corporate Investment Efficiency } \\
\hline \multirow{4}{*}{\multicolumn{5}{|c|}{$\begin{array}{l}\mathrm{H}_{3} \text { : Moderation of Good Corporate Governance is effect of Financial Statement Quality toward Corporate } \\
\text { Investment Efficiency } \\
\mathrm{H}_{4:} \text { Moderation of Good Corporate Governance as effect of Tax Incentives toward Corporate Investment } \\
\text { Efficiency }\end{array}$}} \\
\hline & & & & \\
\hline & & & & \\
\hline & & & & \\
\hline \multicolumn{5}{|c|}{$\mathrm{H}_{5}$ : Good Corporate Governance toward Corporate Investment Efficiency } \\
\hline CIE & Coef. & Std. Err. & $\mathbf{t}$ & $\mathbf{P}>|\mathbf{t}|$ \\
\hline KPK & 3.483585 & 1.75157 & 1.99 & 0.049 \\
\hline TI & $-8.41 \mathrm{e}+07$ & $6.42 \mathrm{e}+07$ & -1.31 & 0.193 \\
\hline GCG & $-7.10 \mathrm{e}+07$ & $2.39 \mathrm{e}+08$ & -0.30 & 0.767 \\
\hline FRQGCG & -100.143 & 50.03242 & -2.00 & 0.048 \\
\hline TIGCG & $2.61 \mathrm{e}+09$ & $1.84 \mathrm{e}+09$ & 1.42 & 0.158 \\
\hline _cons & 1959841 & 8406150 & 0.23 & 0.816 \\
\hline $\mathrm{N}$ & 120 & & R-squared & 0.2683 \\
\hline Prob $>F$ & 0.0000 & & Adj R-squared & 0.2362 \\
\hline \multicolumn{5}{|l|}{ Notes: } \\
\hline \multicolumn{5}{|c|}{$\begin{array}{l}\text { Corporate Investment Efficiency measures with capital expenditure plus R\&D minus acquisition } \\
\text { expenditure minus PPE sales square } 100 \text { divided total asset. Financial Statement Quality is } \\
\text { measures by net income plus depreciation minus cash flow from operation. Tax Incentives measures } \\
\text { with pre-tax in co m e minus current tax burden divided total asset. Good Corporate Governance measures } \\
\text { with composition of firm assets plus opportunity grow plus firm size. }\end{array}$} \\
\hline
\end{tabular}

\section{CONCLUSION}

The results of the first hypothesis test found that there is an effect of the quality of financial reporting on corporate investment efficiency. The results of this study are inversely proportional to the research of Lara et al., (2007). However, this study is consistent with the research of Lai et al., (2014), because 
the high quality of financial statements can improve the efficiency of corporate investment. The results of testing the second hypothesis are found that there is no effect of tax incentives on corporate investment efficiency. The results of the study are consistent with the Lumbantobing (2008) study. However, the results of this study are inversely proportional to the research of Sun et al., (2015), because the provision of tax incentives has not been able to improve the efficiency of investments made by companies. The third hypothesis testing results found that there is an influence of good corporate governance on corporate investment efficiency through the quality of financial reporting. The results of this study are consistent with research by Heenetigala \& Armstrong (2011), because the application of high good corporate governance is able to improve the quality of the company's financial statements so as to improve the efficiency of corporate investment. The fourth hypothesis testing results found that there is no effect of good corporate governance on corporate investment efficiency through tax incentives. The results of this study are inversely proportional to the research of Hanum \& Zulaikha (2013), because the application of good corporate governance and the provision of corporate tax incentives have not been able to improve the efficiency of corporate investment. The results of testing the fifth hypothesis are found that there is no influence of good corporate governance on corporate investment efficiency. The results of this study are consistent with the research of Aluchna (2009), because high corporate governance has not been able to improve the efficiency of corporate investment.

\section{REFERENCE}

Ahuja, G., \& Novelli, E. (2017). Activity Overinvestment: The Case of R\&D. Journal of Management. Aluchna, M. (2009). Does good corporate governance matter? Best practice in Poland. Management Research News, 32(2), 185-198.

Armstrong, C. S., Blouin, J. L., \& Larcker, D. F. (2012). The incentives for tax planning. Journal of Accounting and Economics, 53(1-2), 391-411.

Biddle, G. C., Hilary, G., \& Verdi, R. S. (2009). How does financial reporting quality relate to investment efficiency? Journal of Accounting and Economics.

Bulutoding, L. (2016). Analysis of aggressive tax in terms of good corporate governance company listed on the Indonesia stock exchange (IDX). Man in India, 96(11), 4455-4466.

Cormier Marie-Josée Ledoux Michel Magnan Walter Aerts, D., Cormier, D., Ledoux, M.-J., Magnan, M., \& Aerts, W. (2011). Corporate Governance: The international journal of business in society Corporate governance and information asymmetry between managers and investors. Iss Management Decision, 10(8), 574-589.

Drobetz, W., \& Fix, R. (2003). What are the determinants of the capital structure?

Some evidence for Switzerland. WWZ Woking Paper, 4(3), 1-38.

Du, J., Li, W., Lin, B., \& Wang, Y. (2018). Government integrity and corporate investment efficiency. China Journal of Accounting Research, 11(3), 213-232.

Edvandini, L., Subroto, B., \& Saraswati, E. (2014). Telaah Kualitas Informasi Laporan Keuangan dan 
ISSN 2582-2292

Vol. 3, No. 05 Sep-Oct; 2021

Asimetri Informasi Sebelum dan Setelah Adopsi IFRS. Jurnal Akuntansi Multiparadigma.

Finnerty, J. D., Finnerty, J. D., Emery, D. R., \& Emery, D. R. (2004). The Value of Corporate Control and the Comparable Company Method of Valuation. Financial Management, 33(1), 91-99.

García Lara, Juan \& Garcia Osma, Beatriz \& Penalva, Fernando. (2007). Board of Directors' Characteristics and Conditional Accounting Conservatism: Spanish Evidence. European Accounting Review. 16. 727-755. 10.1080/09638180701706922.

Ghozali, I. (2016). Aplikasi Analisis Multivariate Dengan Program IBM dan SPSS 21. In Aplikasi Analisis Multivariate dengan Pogram iIBM SPSS 21 (p. 113).

Handayani, U. T., Siregar, S. V., \& Elok, T. (2015). Kualitas Laporan Keuangan, Mekanisme Governance, dan Efisiensi Investasi. Jurnal Akuntansi Dan

Keuangan Indonesia.

Hanum, H. R., \& Zulaikha. (2013). Pengaruh Karakteristik Corporate Governance Terhadap Effective Tax Rate (Studi Empiris pada BUMN yang Terdaftar di BEI 2009-2011). Diponegoro Journal of Accounting, 2, 1-10.

Heenetigala, K., \& Armstrong, A. F. (2011). The Impact of Corporate Governance on Firm Performance in an Unstable Economic and Political Environment: Evidence from Sri Lanka. SSRN.

Hope, O. K., \& Thomas, W. B. (2008). Managerial empire building and firm disclosure. Journal of Accounting Research, 46(3), 591-626.

Houcine, A. (2013). Does accounting conservatism affect firm investment efficiency in an emerging market? Evidence from Tunisian context. African J. Accounting, Auditing and Finance, 2(3), 209-232.

Houcine, A. (2017). The effect of financial reporting quality on corporate investment efficiency: Evidence from the Tunisian stock market.

Research in International Business and Finance, 42, 321-337.

Januardi, N. V, \& Afrianto, E. D. (2017). Pengaruh Likuiditas , Leverage ,

Efisiensi Operasi, Perusahaan Terhadap Risiko Sistematis Dan Non- Sistematis. Diponegoro Journal of Management, 6, 1-14.

Jensen, N., \& Meckling, W. (1976). Theory of the firm: Managerial behavior, agency costs, and capital structure. Journal of Financial Economics.

Klapper, L. F., \& Love, I. (2004). Corporate governance, investor protection, and performance in emerging markets. Journal of Corporate Finance.

Klemm, A., \& van Parys, S. (2012). Empirical evidence on the effects of tax incentives. International Tax and Public Finance, 19(3), 393-423.

Kothari, S. P., Leone, A. J., \& Wasley, C. E. (2005). Performance matched discretionary accrual measures. Journal of Accounting and Economics, 39(1), 163-197.

Lai, S. M., Liu, C. L., \& Wang, T. (2014). Increased disclosure and investment efficiency. Asia-Pacific Journal of Accounting and Economics, 21(3), 308-327. 


\section{International Journal of Research in Commerce and Management Studies}

ISSN 2582-2292

Vol. 3, No. 05 Sep-Oct; 2021

Lumbantobing, R. (2008). Studi Mengenai Perbedaan Struktur Modal Perusahaan Penanaman Modal Asing Dengan Perusahaan Modal Dalam Negeri Yang GO Public di Pasar Modal Indonesia. Program Doktor Ilmu Ekonomi Universitas Diponegoro.

Lumbantobing, R. (2008b). Studi Mengenai Perbedaan Struktur Modal Perusahaan Penanaman Modal Asing Dengan Perusahaan Modal Dalam Negeri Yang GO Public di Pasar Modal Indonesia. Program Doktor Ilmu Ekonomi Universitas Diponegoro.

Mahenthrian, S., \& Kasipillai, J. (2014). Influence of Ownership Structure and Corporate Governance on Effective Tax Rates and Tax Planning: Malaysian Evidence. SSRN.

Nam, C. W., \& Radulescu, D. M. (2004). Types of Tax Concessions for Attracting Foreign Direct Investment in Free Economic Zones, 26.

Putri, Wika. Arsanti. (2017). Insentif Pajak dalam Keputusan Investasi. Moneter Journal, 4(2), 132 138.

Rahmawati, A. D., \& Harto, P. (2014). Analisis Pengaruh Kualitas Pelaporan Keuangan dan Maturitas Utang terhadap Efisiensi Investasi. Doponegoro Journal of Accounting, 3, 1-12.

Rego, S. O., \& Wilson, R. (2012). Equity Risk Incentives and Corporate Tax Aggressiveness. Journal of Accounting Research, 50(3), 775-810.

Ross, S. A. (1973). The economic theory of agency: The Principal's Problem. American Economic Review.

Salami, A. King. (2011). Analysis of relationship between share ownership structure, and corporate investment efficiency, Using GSE Market Data (2005-2009). Journal of Accounting and Finance, 11(4)

Tambun, S. dan Bagita (2016). Pengaruh Good Corporate Governance (Gcg) Dan Kinerja Keuangan Terhadap Nilai Perusahaan Dengan Kebijkan Dividen Sebagai Variabel Intervening. Pengaruh Good Corporate Governance (Gcg) Dan Kinerja Keuangan Terhadap Nilai Perusahaan Dengan Kebijkan Dividen Sebagai Variabel Intervening, 147(2), 11-40. 